\title{
Analysis of Low Budget Realization for Local Government Priority Programs: A Case Study on the Transportation Department of DKI Jakarta
}

\author{
Tri Oka Putra \\ triokaputra@gmail.com \\ Universitas Indonesia \\ Indonesia
}

\author{
Christina Juliana \\ christina.juliana@atmajaya.ac.id \\ Universitas Katolik Atmajaya \\ Indonesia
}

\begin{abstract}
This research initiative aims to analyze the performance of Daerah Khusus Ibukota (DKI) Jakarta province from 2013 to 2016 . This assessment is important because the budget realization of the local administration is not maximized. The Department of Transportation was established as the research unit for the present study. The analysis was conducted by comparing the strategic plan related to priority programs for the development of the public transport system, especially road and rail-based transportation. The results of the investigation reveal the existence of certain weaknesses and barriers in the accomplishment of the priority programs. It is concluded that comprehensive strategy management and the measurement of performance are critically required. Hence, this research attempts to develop a suitable and balanced scorecard to instigate improvement in the Department of Transportation's performance.
\end{abstract}

Keywords-performance, priority programs, balanced scorecard

\section{INTRODUCTION}

The way in which the budget realization is targeted is an important measure of performance for an organization. The achievement of this goal is based on the functions of the budget, especially for the public sector, in which the budget should be used (1) as planning tool, (2) as an instrument of control, (3) as a policy mechanism, (4) as a political vehicle, (5) as a means of coordination and communication, (6) as a performance appraisal method, and (7) as a motivational device [1]

Inadequate budget realization is caused by the lack of coordination between an organization's planning and budgeting, especially for activities such as infrastructure development, for example, when a budget for land acquisition is not allocated at the planning stage. Some training and education plans are also known to provide only for consumption expenditures, teacher fees, and a lump-sum for participants, without assigning any budget for the official travel of trainees (Siswanto and Rahayu, 2010). A low level of budget realization also occurs at the regional level including the provincial government of DKI Jakarta, as displayed in the following Table 1.

The table above demonstrates that the realization of the city's Anggaran Pendapatan dan Belanja Daerah (APBD) expenditure every year does not realize nearly 20 percent of the budgeted amount. Thus, a significant portion of the funds budgeted for an activity or purpose remain unused for various reasons. The total wasted amount ranges between 50 and70 trillion based on the number of ABPD in DKI Jakarta. This figure is significant and poses the potential of Indonesia not achieving its planned and budgeted objectives.

The insufficient APBD realization causes a mismatch between policies, programs, and activities planned and their actualization. Further, it tends to hamper the government's priority programs for DKI Jakarta because each of these items is allowed a calculated budget when the APBD is prepared.

One of DKI Jakarta government's priority programs is transportation. This plan takes precedence because of several reasons, including Jakarta Capital City's population growth rate. The Indonesian capital's inhabitants grew at an average rate of $1.07 \%$ between 2010 and 2016 (BPS DKI Jakarta Province). The number of motor vehicles that were registered in DKI Jakarta between 2008 and 2012 evinced an average increase of $8 \%$ per year. Of that number around $98.7 \%$ were private vehicles and only $1.3 \%$ represented public transport, which serves as $26 \%$ of the daily vehicular travel in Jakarta (Head of Jakarta Provincial Transportation Agency, 2013). It is thus vital that the budget for this priority program is realized so that the expected goals of the Jakarta government can be achieved in the short, medium, and long terms.

TABLE I. $\quad$ APBD DKI JAKARTA BUDGET REALIZATION 2013-2016

\begin{tabular}{|c|c|c|c|c|c|c|c|}
\hline \multirow{2}{*}{ Tahun } & \multicolumn{2}{|c|}{ Anggaran } & \multicolumn{2}{c|}{ Realisasi } & \multicolumn{2}{c|}{ \% Realisasi } & \multirow{2}{*}{$\begin{array}{c}\text { Realisasi } \\
\text { APBD }\end{array}$} \\
\cline { 2 - 7 } & Penerimaan & Pengeluaran & Penerimaan & Pengeluaran & Penerimaan & Pengeluaran & PPD \\
\hline 2013 & 50.243 .587 & 50.263 .587 & 48.970 .915 & 41.380 .113 & $97 \%$ & $82 \%$ & $90 \%$ \\
\hline 2014 & 72.905 .494 & 72.905 .494 & 51.041 .851 & 41.879 .363 & $70 \%$ & $57 \%$ & $64 \%$ \\
\hline 2015 & 65.768 .706 & 65.768 .706 & 53.419 .020 & 53.485 .501 & $81 \%$ & $81 \%$ & $81 \%$ \\
\hline 2016 & 62.910 .038 & 62.910 .038 & 59.373 .848 & 51.667 .567 & $94 \%$ & $82 \%$ & $88 \%$ \\
\hline
\end{tabular}

a. Source: Provincial Government of DKI Jakarta; data have been re-processed 
A comprehensive measurement of the performance local governments is required to obtain accurate, detailed, and longstanding information. This study will attempt to analyze the impact of the low realization of APBD with regard to the implementation of priority programs in the field of transportation between the years 2013 and 2016. It will also apply a comprehensive measurement in the form of a balanced scorecard related to the priority programs of the DKI Jakarta provincial government, especially for road and rail-based transportation.

This investigation was conducted on one Satuan Kerja Perangkat Daerah (SKPD), the Transportation Department of the DKI Jakarta province because this regional administrative unit is responsible for the transportation sector. It oversees the development strategies and the amelioration of the transportation system in Jakarta. The analysis is also limited to the priority programs pertaining to the public transportation system of the DKI Jakarta government, especially road and rail-based transport. The examination is constrained in this manner because the lack of public transportation users is the main problem of urban transport in Jakarta. Finally, the budget analysis spans the period between 2013 and 2016 because it compares the Rencana Strategis (Renstra) or the strategic plan with the actual expenditures undertaken in a particular year.

\section{THEORETICAL REVIEW}

\section{A. Local Government}

Law Number 32 of 2004 mentions that the regional government is tasked with the organization of the government affairs conducted by the provincial administration and by the Regional House of Representatives (DPRD) according to the broadest autonomy principles recorded in the systems and principles of the Unitary State of the Republic of Indonesia (NKRI). It names the Governor, Mayor, Regent of DPRD, and other regional officials as local government organizers. Regional development refers to efforts to improve the welfare of the community in terms of income, employment, field of business, access to policy making, competition, as well as pertaining to the increase of the human development index. Thus, the development of an area encompasses a wide variety of social aspects of a community.

A process of establishing and coordinating the stages of activities with the involvement of interested parties is required to achieve regional development objectives. In this case, planning is needed to utilize and to allocate owned resources. In addition, planning is also useful for the conception of the priority scale of some existing problems. Article 2 of the Ministry of Home Affairs Number 54 of 2010 defines several forms of regional development planning including the Regional Long-Term Development Plan (RPJMD) and the Work Plan (Renja). The groundwork of such plans should be transparent, responsive, efficient, effective, accountable, participatory, measurable, fair, and environmentally sound.

\section{B. Regional Finance}

According to Article 1 of the Regulation of the Minister of Domestic Affairs Number 13 Year 2006, regional finance is related to the rights and obligations of the regions in the context of the implementation of local governance that can be assessed by money, including all forms of properties related to the rights and obligations of the region. The management of regional finance covers all activities that include the planning, implementation, administration, reporting, accountability, and supervision of regional finances. In practice, general principles must be fulfilled: the management of finance must be orderly, regulatory, effective, efficient, economical, transparent, responsible, fair, proper, and beneficial.

\section{Regional Budget (APBD)}

Article 1 of Permendagri Number 13 Year 2006 specifies that APBD is a local government financial plan for one year which is discussed and approved jointly by the local government and DPRD. The APBD should be prepared in accordance with the needs and abilities of regional incomes so that the agenda are realistic and can be achieved and development efforts are undertaken according to plan. Also, APBD should also be guided by the RKPD which aims to actualize service to the community.

Renyowijoyo (2010) asserts that the aspect of planning should be directed toward making the whole process of instituting the APBD transparent by involving community participation in the context of decision making, in determining the general direction of the policy, in ascertaining the priority scale, and in the allocation and distribution of resources.

Even if the realization of the targeted budget is one hundred percent it does not necessarily imply that the budget has been maximally utilized and that the financial management has been adequate. Conversely, a low budget realization does not necessarily mean that the allocated budget is said to have failed in its management. A broader analysis of the achievement of the budget realization is required to obtain complete and accurate information.

\section{Performance}

The term performance describes level of achievement in the implementation of an activity, program, or policy in realizing the goals, objectives, mission, and organizational vision contained in the strategic planning of an organization [3]. Performance terms are often used to define the achievements or success rates of individuals and groups of individuals.

According to Mardiasmo (2002), public sector performance measurement systems are aimed at helping managers assess the achievement of a strategy through financial and non-financial measures. This performance measurement system can be used as an organizational control tool. Mardiasmo further explains that performance measurement aims to help in identifying the aspects of planning that have been achieved and those that have not been achieved; in ascertaining the accuracy of resource allocation and decision making; in enhancing public accountability, and in improving institutional communication. The information obtained from the performance appraisal can be evaluated for future improvement of the organization.

Performance measurement is important because the quantifiable evaluation of organizational strategies results in valuable knowledge that can be used for the amelioration of the organization. If information cannot be presented in numerical form, the knowledge gained will not be adequately specific (Kelvin, in Niven, 2003). Hence, measurement is necessary for future improvement.

\section{E. Balanced Scorecard}

The balanced scorecard is a form of performance measurement that observes a balance between short-term and 
long-term goals, between financial size and non-financial measures, between past and future indicators, and between external and internal capabilities [5]. The intended balance is illustrated through four measurement perspectives: financial, customer-related, internal, and innovation and learning. Thus, it is not enough to rely solely on financial indicators generated from past data.
Balanced scorecards expand an organization's business objectives beyond financial measures [5]. Through this method, organizations can measure how they can create value for current and future customers, and how they can improve internal capabilities to achieve their goals.

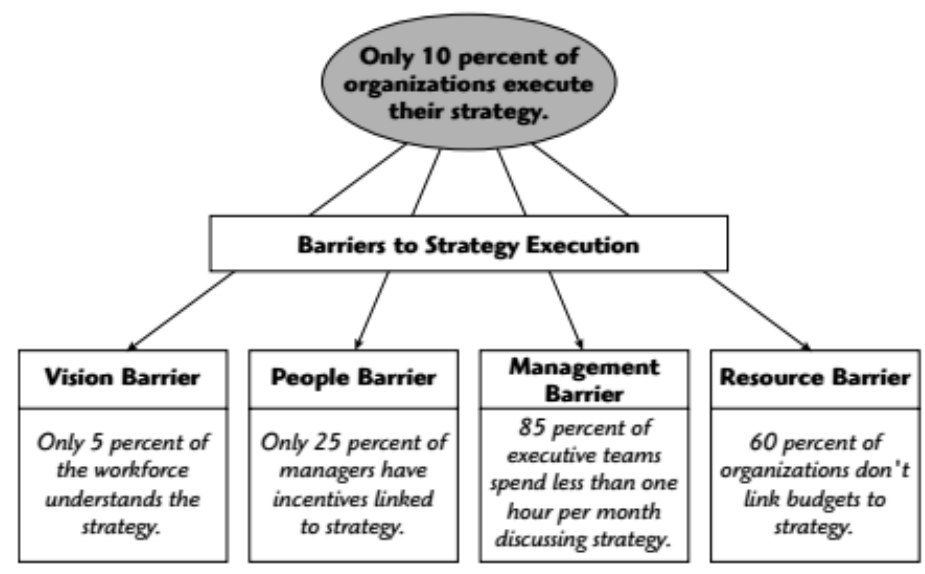

Source: Kaplan dan Norton dalam Riven (2003)

Fig 1. The obstacles to implementing the strategy

The government also needs a balanced scorecard to be able to execute the vision and the mission to be achieved. Riven (2003) claims that the execution of a strategy is more important and more valuable than its preparation. Only 10 percent of organizations implement their strategies because of the obstacles described by Kaplan and Norton (Riven, 2003). The obstacles to implementing the strategy are illustrated in Figure below:

According to Riven (2003), the vision barrier is as an obstacle caused by the lack of understanding of the organizational vision and mission by the many parties involved. On the other hand, the people barrier refers to managers who depend on incentives to achieve goals. Thus, managers are likely to sacrifice long-term targets to achieve short-term targets in financial measures to obtain incentives. Further, resource barriers originate from budgets that are not aligned with organizational strategies and these impediments signal the absence of a predetermined strategy and hinder the achievement the organization's priority objectives. Finally, the management barrier is defined as the management's reluctance to discuss the organizational strategy. It is crucial for management and employees to establish two-way communication and work for mutual benefit. With a balanced scorecard, these constraints can be applied to create a strategy management system to overcome these obstacles so that the vision and mission or the goals of an organization can be achieved.

In the public sector, the organization's mission leads the balanced scorecard. The four perspectives mentioned above, financial, customer-related, internal, and innovation and learning, represent interconnected efforts to achieve that mission. Each perspective should consider the chosen strategy in terms of situation-dependent priority so that a suitable response may be tendered to the challenges and opportunities that arise in the future [6].
The customer's perspective follows the mission in the ranking. Public sector organizations are meant to create value for the customers and all the other perspectives can help serve this cause. If a private sector company is primarily responsible for raising shareholder wealth, the public sector is customerfocused and its priority is to provide the best service to achieve the organization's mission. A financial perspective is also vital, because a balanced scorecard would not be said to be perfect without the measurement of this parameter of organizational health. The appraisal of this factor can help the public sector, for example, achieve the requisite cost reduction. A smaller cost and better efficiency will make investment in the public sector attractive for investors. Further, a balanced scorecard for the public sector must also identify the internal processes that add value for customers. Finally, an evaluation of the growth and development of the abilities, dedication, and alignment of employees can sustain a public sector company as an innovative and learning organization and thus help in the achievement of its goals.

\section{F. Public policy}

O'Toole (2000) defines policy implementation as the features that are developed between the establishment of a clear intention on the part of government to do something, or to stop doing something, and the final impact of a series of actions. There are four variables in public policy: communications, resources, dispositions or attitudes, and bureaucratic structures (Edward III in Agustino, 2006). These four factors must be simultaneously implemented for the successful application of policies because they share an intimate relationship.

\section{G. e-Government}

Presidential Instruction no. 3 of 2003 on National Policies and Strategies describes e-government as an effort to develop electronic governance systems to improve the quality of public services. The development of e-government mechanisms helps to structure management systems and work 
processes in the government environment by optimizing the utilization of information technology.

The blueprint of the e-government application system developed by the Ministry of Communication and Information Technology (DEPKOMINFO) in 2002 describes egovernment related issues as follows:

\section{1) The purpose of e-Government Implementation}

1. Improving the quality of public services through the utilization of IT technology in the governance process

2. Establishing a clean, transparent government, that can effectively respond to demands for change

3. Enhancing the organization, management systems, and work processes of governments

2) Target of e-Government Development

1. Institution of information networks and transactions of quality and affordable public services

2. Establishment of interactive relationships with the business world to enhance and strengthen the ability of the economy to face changes and international trade competition

3. Formation of communication mechanisms between government agencies and provision of facilities for public participation in governance processes

4. Creation of transparent and efficient management systems and work processes to smoothen transactions and services among government agencies

The blueprint of e-government application system mandates certain changes due to the transformation of work systems from manual to electronic platforms. Certain processes of change must be managed properly for a smooth transition to occur: work culture, work process (business process), standard operating procedures, political policy, rules and regulations, and leadership.

\section{RESEARCH METHODS}

This qualitative study is a case study. The investigation was conducted through interviews and observations without formal measurement [9]. The method used to develop the case study comprised the analysis of a phenomenon with regard to its effects on the object of this study. In addition, this study performed in-depth evaluation of some aspects related to the discussed phenomena to obtain accurate and complete information.

The Department of Transportation was used as the research unit for this study. It represents a Regional Device Work Unit (SKPD) of DKI Jakarta province and its primary duty is to execute all transportation related matters (Governor of DKI Jakarta, 2009) and to address the varied transportation problems in Jakarta.

The vision of the Jakarta Transportation Department is "To create a New Jakarta through the provision of reliable, modern and competitive transportation services at the Asia level, with public transport as a primary service." The Mission statement reads:

a. Achieve safe, smooth, secure, convenient, and integrated transportation services; b. Achieve an informative transportation service based on information and communication technology;

c. Achieve environmentally friendly transportation and support accessibility for persons with disabilities;

d. Achieve affordable transportation costs for the community.

The analysis conducted in this study compared the Renstra between 2013 and 2017 to the actual achievements accrued in between 2013 and 2016 only, because the Lembaga Kajian Pembangunan Daerah (LKPD) 2017 is still undergoing the Badan Pemeriksa Keuangan (BPK) audit process and it thus cannot be used as a reference. The effected comparison describes the problems and the constraints, the advantages and disadvantages, and the responses of the provincial 
government of DKI Jakarta to these comparative results. After the performance of Dinas Perhubungan was comprehensively evaluated, a balanced scorecard was developed as a tool for local governments to achieve their vision and mission. The grounding for each appropriate perspective to be used as goals, targets, and initiatives that must be taken is discussed in detail in the next section.

\section{RESEARCH RESULT}

Certain aspects of improvement are necessary for the development of transportation system in Jakarta to fulfill the established and expected goals. The issues pertaining to unrealized budgets should be addressed so that the implementation of planned activities is not impeded. No comprehensive, measurable, and achievable strategy and measurement systems are yet instituted. Thus, the execution of activities takes longer than planned or the results of activities are not optimal. The achievement of the strategic plan evidences the problems and obstacles in the implementation of the organizational activities of the Transportation Department of the DKI Jakarta province.

The overcoming of problems and constraints requires a response that is more than just moving budgeted activities to the next financial year.

This outcome occurs because of the existing lack of alignment between the vision and mission and the initiatives that must be performed to achieve the stated goals. Hence, the potential of unanticipated problems at the time of planning also increases.

TABLE II. A ACHIEVEMENT OF PERFORMANCE INDICATORS IN RENSTRA OF TRANSPORTATION DEPARTMENT OF DKI JAKARTA PROVINCE

\begin{tabular}{|c|c|c|c|c|c|c|c|c|}
\hline \multirow{3}{*}{ Indikator Kinerja Utama } & \multicolumn{8}{|c|}{ Pencapaian Setiap Tahun } \\
\hline & \multicolumn{2}{|c|}{2013} & \multicolumn{2}{|c|}{2014} & \multicolumn{2}{|c|}{2015} & \multicolumn{2}{|c|}{2016} \\
\hline & Target & Realis asi & Target & Realisasi & Target & Realisasi & Target & Realisasi \\
\hline $\begin{array}{l}\text { Jum lah halte busway yang } \\
\text { terintegrasi dengan stasiun MRT }\end{array}$ & - & - & - & - & - & - & $\begin{array}{c}1 \text { dokumen } \\
\text { perencanaan }\end{array}$ & $\begin{array}{l}1 \text { dokumen } \\
\text { perencanaan }\end{array}$ \\
\hline $\begin{array}{l}\text { Jumlah penumpang busway per } \\
\text { hari }\end{array}$ & 400.000 & 308,821 & 550.000 & 305,836 & 730.000 & 282,056 & 850.000 & 338,923 \\
\hline $\begin{array}{l}\text { Persentase terbangunnya fisik } \\
\text { koridor } 13\end{array}$ & $21,43 \%$ & & $57,14 \%$ & $0,00 \%$ & $78,57 \%$ & $38,12 \%$ & $100 \%$ & $96,86 \%$ \\
\hline $\begin{array}{l}\text { Persentase terbangunnya fisik } \\
\text { koridor } 14\end{array}$ & - & - & $50 \%$ & $\propto$ & $100 \%$ & $\propto \%$ & - & - \\
\hline $\begin{array}{l}\text { Persentase terbangunnya fisik } \\
\text { koridor } 15\end{array}$ & - & - & - & - & $50 \%$ & $\propto \%$ & $50 \%$ & $\%$ \\
\hline $\begin{array}{l}\text { Persentase prasarana penunjang } \\
\text { busway koridor } 13 \text { yang } \\
\text { terbangun }\end{array}$ & - & - & $\begin{array}{c}2 \text { dokumen } \\
\text { pe rencanaan }\end{array}$ & $\begin{array}{c}2 \text { dokumen } \\
\text { perencanaan }\end{array}$ & $100 \%$ & $<100 \%$ & - & $?$ \\
\hline $\begin{array}{l}\text { Persentase prasarana penunjang } \\
\text { busway koridor } 14 \text { yang } \\
\text { terbangun }\end{array}$ & - & - & $\begin{array}{l}2 \text { dokumen } \\
\text { pe rencanaan }\end{array}$ & - & - & $0 \%$ & $100 \%$ & $0 \%$ \\
\hline $\begin{array}{l}\text { Persentase prasarana penunjang } \\
\text { busway koridor } 15 \text { yang } \\
\text { terbangun }\end{array}$ & $\cdot$ & $\cdot$ & $\begin{array}{c}2 \text { dokumen } \\
\text { pe rencanaan }\end{array}$ & - & - & $\cdot$ & - & $\cdot$ \\
\hline Headway rata-rata (menit) & 15 & 15,8 & 10 & PMP & 7 & PMP & 5 & PMP \\
\hline $\begin{array}{l}\text { Jumlah pengadaan armada } \\
\text { busway }\end{array}$ & 275 & 125 & 200 & PMP & 200 & PMP & 180 & PMP \\
\hline $\begin{array}{l}\text { Perda pe mbe ntukan BUMD } \\
\text { bid ang transportasi PT } \\
\text { Transjakarta }\end{array}$ & 1 & 1 & - & - & - & - & - & - \\
\hline $\begin{array}{l}\text { Berfungsinya ITS pada koridor } \\
\text { busway }\end{array}$ & Tahap III & Tahap III & Tahap IV & Tahap IV & Tahap V & Tahap V & Tahap VI & Tahap VI \\
\hline $\begin{array}{l}\text { Persentase jalur MRT Lb. Bulus - } \\
\text { Bundaran HI yang dapat } \\
\text { disele saikan }\end{array}$ & - & - & $25 \%$ & $\%$ & $50 \%$ & $\%$ & $75 \%$ & $52 \%$ \\
\hline $\begin{array}{l}\text { Jumlah dokumen prencanaan } \\
\text { MRT Bundaran } \mathrm{HI} \text { - Kampung } \\
\text { Bandan }\end{array}$ & - & - & 1 & 1 & - & $\cdot$ & - & - \\
\hline $\begin{array}{l}\text { Jumlah dokumen pembiayaan } \\
\text { MRT Bundaran HI - Kampung } \\
\text { Bandan }\end{array}$ & - & - & 1 & 1 & - & - & - & - \\
\hline $\begin{array}{l}\text { Jum lah dokumen le lang } \\
\text { konstruksi MRT Bund aran } \mathrm{HI} \text { - } \\
\text { Kampung Band an }\end{array}$ & - & $\cdot$ & $\cdot$ & - & 1 & 0 & - & $\cdot$ \\
\hline $\begin{array}{l}\text { Jumlah dokumen pere ncanaan } \\
\text { MRT koridor Barat - Timur }\end{array}$ & - & - & - & - & 1 & 0 & - & - \\
\hline Panjang jaringan LRT $(\mathrm{Km})$ & - & - & - & - & - & - & - & - \\
\hline
\end{tabular}

b. Source: PPID Jakarta Province 
Further, various parties are required to collaborate in the building of the public transportation system. The city government also needs external parties such as private companies to contribute to this development. This positive impact can only occur when PT Transjakarta can cooperate withits partner operators in terms of procurement of a Transjakarta fleet so that when the provincial government faces constraints such as lack of budget or procurement problems, the aim of increasing the vehicles can still be achieved through private contribution.

\section{DISCUSSION}

Comprehensive performance measures are required for the appropriate implementation of the DKI Jakarta provincial government's activities. The balanced scorecard method has been used for this case study. The stated vision and mission of the Department of Transport can be employed to prepare a balanced scorecard based on a strategic theme for each perspective as follows:

\section{A. Stakeholder Perspective (Society)}

The strategic theme required for this perspective is: How can the public transport usage by the community be amplified? This desired outcome is the essential to overcome the growing problem of congestion in Jakarta. The use of private vehicles will automatically be controlled when the public becomes more interested in using public transportation. The results enumerated below must be achieved from the stakeholder standpoint.

1) Transport costs should be affordable to the whole community and the following actions should be taken:

a) Establish lower bus and other public transport fares

b) Provide facilities and infrastructure for school transportation

2) Provide environmentally friendly transportation, with the following initiatives:

Offer supporting equipment and technology for the use of environmentally friendly fuel for motor vehicles

3) Provide non-motorized transportation infrastructure through actions such as:

a) Facilitation of pedestrian and bicycle-only lanes, especially in public transport corridors and residential areas

b) Building transportation infrastructure to meet the needs of people with disabilities

c) Executing motor vehicle free days

\section{B. Financial Perspective}

The strategic themes needed from this outlook include:

1) The improvement of budget efficiency by reducing costs so that the existing budget can accord the potential for the performance of other beneficial activities. In addition, if the maximum service can be offered at minimal cost, external parties will also become interested in making an investment in the sector. The achievement of such financial health can occur through:

a) The reduction of trial and error activities b) The utilization of information technology infrastructure

c) The implementation of e-budgeting

2) Budget planning must be accurate and fully realizable and the organization must be able to execute the predetermined plan. The maximization of the budget will provide value to the community and can be accomplished by:

a) Improving accountable and transparent financial management and budget realization

b) Following BPK's recommendations on LKPD

c) Implementing GCG particularly with regard to efficiency, transparency, and control in financial management through the execution of e-governance.

\section{Internal Process Perspective}

Certain strategic themes are pivotal to the achievement of effective internal processes:

1) The improvement and increase of public transportation infrastructure is vital because superior transportation systems must be supported by the requisite networks. Hence,

a) Urban transport facilities must be augmented

b) Bus fleets should be procured by Pemprov and/or other operators

c) Mass Rapid Transit (MRT) and Light Rail Transit (LRT) systems must be constructed

2) Support infrastructure for the transportation system must be created.

a) Terminals must be revitalized

b) Management and traffic engineering infrastructure should be built and/or maintained

c) Systems, facilities, networks and regulations supporting traffic control must be instituted

d) ITS that can provide information to public transport users should be developed

e) Cooperation is necessary with application developers to provide real time information on public transport to users

f) Traffic management initiatives must be taken and traffic restrictions should be applied on private vehicles in certain areas

3) The quality of service to public transport users should be enhanced. In addition to infrastructure factors, quality is also important in encouraging people to use public transportation. When the community experiences good service, it will prefer to use public transportation.

a) Minimum service standards must be set. 
b) Public transport institutions must be augmented so that their services encompass special management initiatives to ensure that the standards of care are maintained and to minimize the potential problems such as accidents that may occur.

c) The addition and structuring of public transportation routes is needed to arouse the public's interest in using public transportation.

d) The public transport fleet should be rejuvenated to ensure that all public transport is roadworthy.

e) Economic life limits for each public transport must be applied to avoid unsuitable road fleets.

\section{Growth and Learning Perspective}

The strategic themes needed in this perspective are:

1) Increasing the competence of the human resources of the regional government apparatus is necessary so that every employee can provide maximum productivity to achieve the organizational mission. Hence,

a) Productivity of related systems should be enhanced

b) Regular training must be conducted for employees in accordance with their duties and functions

c) Performance-based incentives should be instituted so employees can contribute to the achievement of goals

2) Utilizing information and communication technology to improve services will help in providing services to the community both in terms of quality and time. Thus,

a) Digitization of service systems must be initiated

b) The service manual should be digitally replaced for efficiency of time, quality, and quantity

\section{CONCLUSION}

The results reveal the seriousness of the provincial government of DKI Jakarta to build a good public transportation system. This is seen in its efforts to repair the existing transportation or in the construction of new transportation infrastructure. Nevertheless, there are still certain aspects that need to be fixed for the expected goals to be achieved as planned. Budget issues that cannot be realized should be addressed so that the implementation of activities that have been budgeted are not impeded.

The current performance indicators are insufficient for the achievement of the stated goals. This research project found that some problems and obstacles are still faced by the DKI Jakarta provincial government in accomplishing its objectives because the application of local planning principles has not been maximal, transparent, responsive, efficient, effective, accountable, participatory, measurable, fair, and environmentally sound.

To comply with these principles, it is necessary for the Department of Transportation to develop a balanced scorecard as a means of planning, controlling, and evaluating the achievement of its objectives. Such a balanced scorecard can clarify and harmonize the vision and mission and the initiatives taken for their achievement through the consideration of the four perspectives of stakeholders, finance, internal processes, and learning and growth. A balanced scorecard is also required to overcome obstacles in strategy implementation: the barriers of vision, people, management, and resources.

\section{SUGGESTIONS}

It is recommended that the DKI Jakarta provincial government should apply the balanced scorecard that has been compiled by this study and should integrate it into its previous measurement format such as the Laporan Akuntabilitas Kinerja Instansi Pemerintah (LAKIP) which has become the standard report on the accountability and performance of government institutions. The integration in question should include key performance indicators that are non-technical and that represent triggers of organizational performance which are not yet incorporated within the LAKIP.

By applying the balanced scorecard, a clarity of direction and focus of activities may be obtained in accordance with the vision, mission, goals, and strategies previously planned by the government organizations. In addition, comprehensive and accurate information and data related to the Pemprov status will be obtained. This will help the DKI Jakarta provincial government in instituting further policy modifications on its transportation services with the development of political, economic, social, and technological conditions.

\section{ACKNOWLEDGMENT}

This research was supported by University of Indonesia. We thank Juliana, Ms for assistance with greatful advice and comments that greatly improved the manuscript. We would also like to show our gratitude to the reviewers for their socalled insights.

\section{REFERENCES}

[1] Nordiawan, D., Putra I. S., \& Rahmawati, M. (2012). Akuntansi sektor publik. Jakarta: Salemba Empat.

[2] Renyowijoyo, M., (2010). Akuntansi sektor publik: Organisasi Non laba (2nd ed). Jakarta: Mitra Wacana Media.

[3] Mahsun, M. (2006). Pengukuran kinerja sektor publik. Yogyakarta: BPFE UGM

[4] Mardiasmo. (2002). Akuntansi sektor publik. Yogyakarta: ANDI.

[5] Kaplan, R. S., \& Norton, D.P. (1996). The balanced scorecard: translating strategy into action. Boston: Harvard Business School Press.

[6] Riven, P. R. (2003). Balanced scorecard step-by-step for government and not-for-profit agencies. New Jersey: John Wiley and Son, Inc.

[7] O'Toole Jr. L. J. (2000). Research on policy implementation: assessment and prospects. Texas: Journal of Public Administration Research and Theory.

[8] Agustino, L. (2006). Dasar-dasar kebijakan publik. Bandung: CV. Alfabeta.

[9] Marczyk, G., DeMatteo, D., \& Festinger, D. (2005). Essentials of research design and methodology. New Jersey: John Wiley \& Sons, Inc. 